\title{
Vertical distribution of methane oxidation and methanotrophic response to elevated methane concentrations in stratified waters of the Arctic fjord Storfjorden (Svalbard, Norway)
}

\author{
S. Mau ${ }^{1,2}$, J. Blees ${ }^{3}$, E. Helmke ${ }^{2}$, H. Niemann ${ }^{3}$, and E. Damm ${ }^{2}$ \\ ${ }^{1}$ Max Planck Institute for Marine Microbiology, Celsiusstrasse 1, 28359 Bremen, Germany \\ ${ }^{2}$ Alfred Wegener Institute for Marine and Polar Research, Am Handelshafen 12, 27570 Bremerhaven, Germany \\ ${ }^{3}$ Department of Environmental Sciences, University of Basel, Bernoullistrasse 30, 4056 Basel, Switzerland \\ Correspondence to: H. Niemann (helge.niemann@unibas.ch)
}

Received: 7 March 2013 - Published in Biogeosciences Discuss.: 8 April 2013

Revised: 30 July 2013 - Accepted: 14 August 2013 - Published: 7 October 2013

\begin{abstract}
The bacterially mediated aerobic methane oxidation $\left(\mathrm{MO}_{\mathrm{x}}\right)$ is a key mechanism in controlling methane $\left(\mathrm{CH}_{4}\right)$ emissions from the world's oceans to the atmosphere. In this study, we investigated $\mathrm{MO}_{\mathrm{x}}$ in the Arctic fjord Storfjorden (Svalbard) by applying a combination of radio-tracerbased incubation assays $\left({ }^{3} \mathrm{H}-\mathrm{CH}_{4}\right.$ and $\left.{ }^{14} \mathrm{C}_{-} \mathrm{CH}_{4}\right)$, stable $\mathrm{C}$ $\mathrm{CH}_{4}$ isotope measurements, and molecular tools (16S rRNA gene Denaturing Gradient Gel Electrophoresis (DGGE) fingerprinting, pmoA- and $m x a F$ gene analyses). Storfjorden is stratified in the summertime with melt water (MW) in the upper $60 \mathrm{~m}$ of the water column, Arctic water (ArW) between 60 and $100 \mathrm{~m}$, and brine-enriched shelf water (BSW) down to $140 \mathrm{~m} . \mathrm{CH}_{4}$ concentrations were supersaturated with respect to the atmospheric equilibrium (about 3-4 nM) throughout the water column, increasing from $\sim 20 \mathrm{nM}$ at the surface to a maximum of $72 \mathrm{nM}$ at $60 \mathrm{~m}$ and decreasing below. $\mathrm{MO}_{\mathrm{x}}$ rate measurements at near in situ $\mathrm{CH}_{4}$ concentrations (here measured with ${ }^{3} \mathrm{H}-\mathrm{CH}_{4}$ raising the ambient $\mathrm{CH}_{4}$ pool by $<2 \mathrm{nM}$ ) showed a similar trend: low rates at the sea surface, increasing to a maximum of $\sim 2.3 \mathrm{nM} \mathrm{day}^{-1}$ at $60 \mathrm{~m}$, followed by a decrease in the deeper ArW/BSW. In contrast, rate measurements with ${ }^{14} \mathrm{C}-\mathrm{CH}_{4}$ (incubations were spiked with $\sim 450 \mathrm{nM}$ of ${ }^{14} \mathrm{C}_{-} \mathrm{CH}_{4}$, providing an estimate of the $\mathrm{CH}_{4}$ oxidation at elevated concentration) showed comparably low turnover rates $\left(<1 \mathrm{nM} \mathrm{day}^{-1}\right)$ at $60 \mathrm{~m}$, and peak rates were found in ArW/BSW at $\sim 100 \mathrm{~m}$ water depth, concomitant with increasing ${ }^{13} \mathrm{C}$ values in the residual $\mathrm{CH}_{4}$ pool. Our results indicate that the $\mathrm{MO}_{\mathrm{x}}$ community in the surface MW is adapted to relatively low $\mathrm{CH}_{4}$ concentrations. In con-
\end{abstract}

trast, the activity of the deep-water $\mathrm{MO}_{\mathrm{x}}$ community is relatively low at the ambient, summertime $\mathrm{CH}_{4}$ concentrations but has the potential to increase rapidly in response to $\mathrm{CH}_{4}$ availability. A similar distinction between surface and deepwater $\mathrm{MO}_{\mathrm{x}}$ is also suggested by our molecular analyses. The DGGE banding patterns of 16S rRNA gene fragments of the surface MW and deep water were clearly different. A DGGE band related to the known type $\mathrm{I} \mathrm{MO}_{\mathrm{x}}$ bacterium Methylosphaera was observed in deep BWS, but absent in surface MW. Furthermore, the Polymerase Chain Reaction (PCR) amplicons of the deep water with the two functional primers sets $p m o A$ and $m x a F$ showed, in contrast to those of the surface MW, additional products besides the expected one of 530 base pairs (bp). Apparently, different $\mathrm{MO}_{\mathrm{x}}$ communities have developed in the stratified water masses in Storfjorden, which is possibly related to the spatiotemporal variability in $\mathrm{CH}_{4}$ supply to the distinct water masses.

\section{Introduction}

Methane $\left(\mathrm{CH}_{4}\right)$ is a potent greenhouse gas with a global warming potential that exceeds carbon dioxide $\left(\mathrm{CO}_{2}\right)$ 23fold over a $100 \mathrm{yr}$ timescale and is, after water vapor and $\mathrm{CO}_{2}$, the most important greenhouse gas (IPCC, 2007). Substantial research efforts have consequently been made to understand its sources and sinks. A large part of oceanic $\mathrm{CH}_{4}$ is generated under reduced conditions in anoxic marine sediments, predominantly through microbially mediated 
$\mathrm{CO}_{2}$ reduction and disproportionation of methylated substrates (Whiticar, 1999; Hinrichs and Boetius, 2002; Formolo, 2010). Sedimentary $\mathrm{CH}_{4}$ is also formed by thermal breakdown of organic matter and, although of lesser importance, serpentinization and Fischer-Tropsch reaction, both occurring at high temperature and pressure. In addition, conspicuous $\mathrm{CH}_{4}$ concentration maxima in oxic water layers provided indications for $\mathrm{CH}_{4}$ production under oxic conditions, possibly mediated by yet unknown microbes using dimethylsulfoniopropionate (DMSP) (Damm et al., 2010) or methylphosphonic acid (MPn) (Karl et al., 2008; Metcalf et al., 2012) as substrate. However, despite the apparent ubiquity of methanogenesis in marine systems and the large area covered by oceans, comparably little $\mathrm{CH}_{4}$ is liberated from the oceans into the atmosphere because of microbial consumption (Reeburgh, 2007; IPCC, 2007). About $80 \%$ of sedimentary $\mathrm{CH}_{4}$ is consumed in reduced sediments as a result of the anaerobic oxidation of methane (AOM) with sulfate as the terminal electron acceptor (Barnes and Goldberg, 1976; Reeburgh, 1976; Martens and Berner, 1977; Reeburgh, 2007; Knittel and Boetius, 2009). Finally, aerobic $\mathrm{CH}_{4}$-oxidizing bacteria at the sediment surface and/or in the water column (belonging to the Alpha- (type II) or Gammaproteobacteria (type $\mathrm{I}$ and type $\mathrm{X}$ )) consume $\mathrm{CH}_{4}$ that has bypassed the anaerobic microbial filter according to the following reaction (Hanson and Hanson, 1996; Murrell, 2010):

$\mathrm{CH}_{4}+2 \mathrm{O}_{2} \rightarrow \mathrm{CO}_{2}+2 \mathrm{H}_{2} \mathrm{O}$.

Several techniques have been used to quantify aerobic methane oxidation $\left(\mathrm{MO}_{\mathrm{x}}\right)$ rates (Reeburgh, 2007). A common method is to incubate water column or sediment samples with radio-labeled tracers such as ${ }^{14} \mathrm{C}-\mathrm{CH}_{4}$ or ${ }^{3} \mathrm{H}-\mathrm{CH}_{4}$ (Reeburgh et al., 1991; Valentine et al., 2001; Niemann et al., 2006; Mau et al., 2012), which has proven to be highly sensitive. During the incubation, ${ }^{14} \mathrm{C}-\mathrm{CH}_{4}$ or ${ }^{3} \mathrm{H}-\mathrm{CH}_{4}$ is converted at the same rate as the natural, non-labeled $\mathrm{CH}_{4}$ to ${ }^{14} \mathrm{CO}_{2}$ and ${ }^{14} \mathrm{C}$-biomass or ${ }^{3} \mathrm{H}_{2} \mathrm{O}$. Despite the importance of water column $\mathrm{MO}_{\mathrm{x}}$ controlling oceanic $\mathrm{CH}_{4}$ emission to the atmosphere, only a small number of water column $\mathrm{MO}_{\mathrm{x}}$ rate measurements exist, which is particularly true for high-latitude environments (Ward and Kilpatrick, 1990; Griffiths et al., 1982). The available data show a large scatter of rates over several orders of magnitude (Fig. 1), but factors controlling $\mathrm{MO}_{\mathrm{x}}$ activity such as temporal variations in $\mathrm{CH}_{4}$ availability (e.g., Mau et al., 2007a, b; Damm et al., 2007) and the activity of the present $\mathrm{MO}_{\mathrm{x}}$ community during time periods with elevated $\mathrm{CH}_{4}$ availability are not well constrained. Our aims were to investigate $\mathrm{MO}_{\mathrm{x}}$ rates at ambient and at elevated $\mathrm{CH}_{4}$ concentrations as well as to determine differences between $\mathrm{MO}_{\mathrm{x}}$ communities thriving at different $\mathrm{CH}_{4}$ concentrations in a natural marine environment. As a model system, we chose the fjord Storfjorden (Svalbard), which is characterized by seasonal stratification, separating distinct water masses with different $\mathrm{CH}_{4}$ sources during summer time.

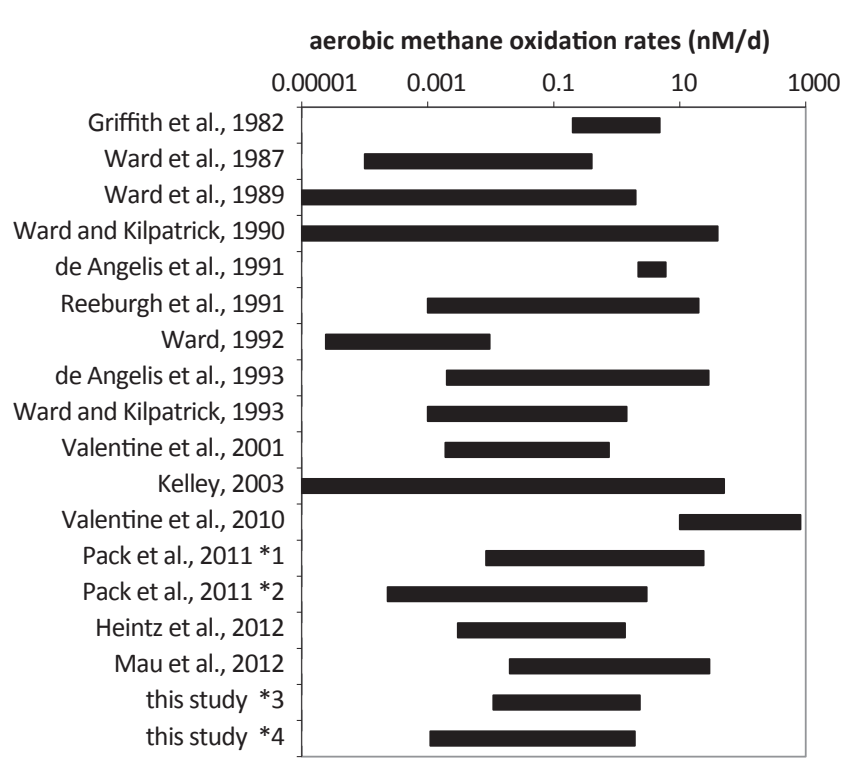

Fig. 1. Range of methane oxidation rates measured at different locations in the ocean water column derived from tracer incubations using ${ }^{3} \mathrm{H}_{-}-\mathrm{CH}_{4}$ (Reeburgh et al., 1991; Valentine et al., 2001, 2010; Heintz et al., 2012, Mau et al., 2012) or ${ }^{14} \mathrm{C}_{-} \mathrm{CH}_{4}$ (all others). Pack et al. (2011) compared incubations with ${ }^{3} \mathrm{H}_{-}-\mathrm{CH}_{4}(* 1)$ and incubations with low-level ${ }^{14} \mathrm{C}_{-} \mathrm{CH}_{4}(* 2)$ that were measured with accelerator mass spectrometry. In this study we compared incubations with ${ }^{3} \mathrm{H}-\mathrm{CH}_{4}\left({ }^{* 3}\right)$ and incubations with ${ }^{14} \mathrm{C}-\mathrm{CH}_{4}\left({ }^{* 4}\right)$.

\section{Material and methods}

\subsection{Study site}

Storfjorden is located in the Svalbard Archipelago between the islands Spitsbergen, Barentsøya, and Edgeøya (Fig. 2). $\mathrm{CH}_{4}$ concentrations in the fjord water exceed atmospheric equilibrium concentration throughout the water column by a factor of 2-16, although surface water $\mathrm{CH}_{4}$ is of a different origin compared to the $\mathrm{CH}_{4}$ in subsurface waters (Damm et al., 2008). Surface waters contain recently produced, ${ }^{13} \mathrm{C}$-depleted $\mathrm{CH}_{4}$, which was proposed to result from a summer phytoplankton bloom producing methylated compounds such as DMSP, which is a potential substrate for methylotrophic methanogenesis. Other potential methanogenic substrates such as methylphosphonates were not investigated in the study area. $\mathrm{A} \mathrm{CH}_{4}$ productionremoval cycle appears to be established in the surface water as reflected by varying $\mathrm{CH}_{4}$ concentrations and ${ }^{13} \mathrm{C}-\mathrm{CH}_{4}$ values (Damm et al., 2008). In contrast, deeper water contains $\mathrm{CH}_{4}$ that is mixed into the bottom water as a result of brine-enriched shelf water (BSW) formation during wintertime causing enhanced turbulence and repeatedly occurring resuspension of sediments releasing $\mathrm{CH}_{4}$ (Damm et al., 2007). The winter-released $\mathrm{CH}_{4}$ is then trapped by increasing water stratification during warmer seasons, and ongoing $\mathrm{CH}_{4}$ consumption leads to a ${ }^{13} \mathrm{C}$-enriched isotopic signature 


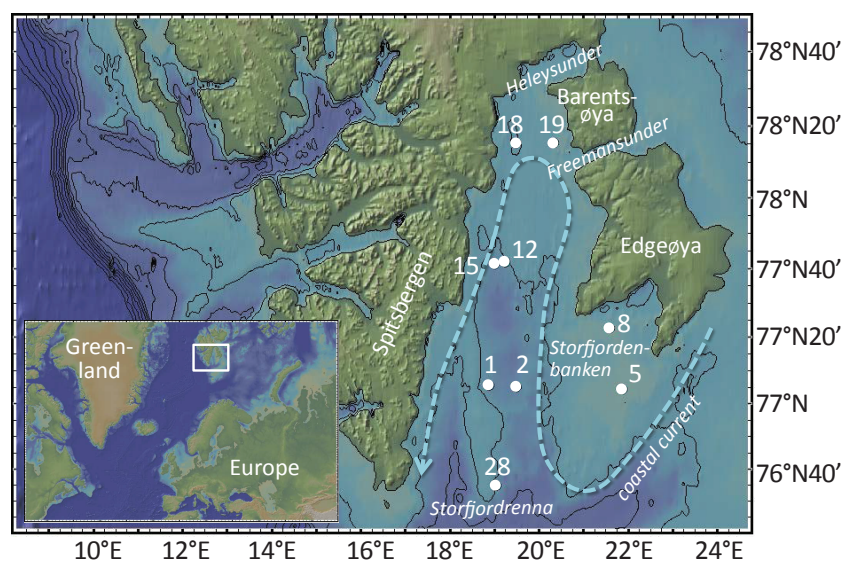

Fig. 2. Locations of the stations in Storfjorden. Stations are marked by white dots and station numbers. The coastal current is indicated by a dashed blue arrow. Contours are drawn every $100 \mathrm{~m}$ until $1000 \mathrm{~m}$ water depth

of the residual $\mathrm{CH}_{4}$. During summertime, the water column is stratified, with surface melt water (MW) and intermediate Arctic water (ArW) constituting the upper water column, while denser BSW is restricted to deep basins (Loeng, 1991). The residence time of the high-salinity water in deeper layers (90-246 days) is longer than the fjord's surface waters (51-141 days) (Geyer et al., 2009).

\subsection{Sampling}

Water samples were collected from nine stations in Storfjorden and at one open-ocean station $\left(70^{\circ} 35.913^{\prime} \mathrm{N}\right.$, $\left.10^{\circ} 51.591^{\prime} \mathrm{E}\right)$ during a cruise with RV Heincke in August 2010 (Fig. 2, Table 1). The Storfjorden stations were aligned along the cyclonic coastal current flowing into Storfjorden along Edgeøya and out along Spitsbergen (Loeng, 1991; Skogseth et al., 2005) (Fig. 2). We intended to sample and compare the fjord's upper and lower water column because of the different $\mathrm{CH}_{4}$ sources and water residence times. We sampled vertical profiles throughout the water column, thus recovering samples from MW, ArW, and BSW. All water masses were subsampled for chemical/biogeochemical analyses (method 2.3 and 2.4), but we focused on the MW and BSW for molecular analyses (method 2.5). Specific water depths were sampled with a CTD/rosette sampler equipped with twelve 5L Niskin bottles, a Sea-Bird SBE 911 plus CTD and an SBE 43 oxygen sensor for online monitoring of salinity, temperature, pressure, and dissolved oxygen.

\section{3 $\mathrm{CH}_{4}$ concentrations and stable isotope composition}

Aliquots of seawater were immediately subsampled from the Niskin bottles using $1 \mathrm{~L}$ glass bottles for measurements of in situ $\mathrm{CH}_{4}$ concentrations. $\mathrm{CH}_{4}$ was extracted from the water by vacuum-ultrasonic treatment within a few hours af-
Table 1. Locations of stations and performed analyses.

\begin{tabular}{|c|c|c|c|}
\hline Station & Latitude & Longitude & Analysis \\
\hline 1 & $77^{\circ} 05.64^{\prime} \mathrm{N}$ & $18^{\circ} 52.67^{\prime} \mathrm{E}$ & {$\left[\mathrm{CH}_{4}\right], \mathrm{MO}_{\mathrm{x}}$-rates, $\delta^{13} \mathrm{C}-\mathrm{CH}_{4}$} \\
\hline 2 & $77^{\circ} 05.23^{\prime} \mathrm{N}$ & $19^{\circ} 29.69^{\prime} \mathrm{E}$ & $\begin{array}{l}{\left[\mathrm{CH}_{4}\right], \mathrm{MO}_{\mathrm{x}} \text {-rates time series, }} \\
\text { DGGE, pmoA, mxaF }\end{array}$ \\
\hline 5 & $77^{\circ} 04.54^{\prime} \mathrm{N}$ & $21^{\circ} 52.25^{\prime} \mathrm{E}$ & $\begin{array}{l}{\left[\mathrm{CH}_{4}\right], \mathrm{MO}_{\mathrm{x}} \text {-rates, } \delta^{13} \mathrm{C}_{-} \mathrm{CH}_{4} \text {, }} \\
\text { DGGE, pmoA, mxaF }\end{array}$ \\
\hline 8 & $77^{\circ} 22.80^{\prime} \mathrm{N}$ & $21^{\circ} 35.43^{\prime} \mathrm{E}$ & {$\left[\mathrm{CH}_{4}\right], \mathrm{MO}_{\mathrm{x}}$-rates, $\delta^{13} \mathrm{C}-\mathrm{CH}_{4}$} \\
\hline 12 & $77^{\circ} 41.91^{\prime} \mathrm{N}$ & $19^{\circ} 14.49^{\prime} \mathrm{E}$ & $\begin{array}{l}{\left[\mathrm{CH}_{4}\right], \mathrm{MO}_{\mathrm{x}} \text {-rates, } \delta^{13} \mathrm{C}_{-} \mathrm{CH}_{4} \text {, }} \\
\text { DGGE, pmoA, mxaF }\end{array}$ \\
\hline 15 & $77^{\circ} 41.45^{\prime} \mathrm{N}$ & $19^{\circ} 00.16^{\prime} \mathrm{E}$ & {$\left[\mathrm{CH}_{4}\right], \mathrm{MO}_{\mathrm{x}}$-rates, $\delta^{13} \mathrm{C}-\mathrm{CH}_{4}$} \\
\hline 18 & $78^{\circ} 15.29^{\prime} \mathrm{N}$ & $19^{\circ} 29.07^{\prime} \mathrm{E}$ & $\begin{array}{l}{\left[\mathrm{CH}_{4}\right], \mathrm{MO}_{\mathrm{x}} \text {-rates, } \mathrm{MO}_{\mathrm{x}} \text {-rates }} \\
\text { time series, }{ }^{13} \mathrm{CH}_{4}, \mathrm{DGGE}, \\
\text { pmoA, mxaF }\end{array}$ \\
\hline 19 & $78^{\circ} 15.41^{\prime} \mathrm{N}$ & $20^{\circ} 20.14^{\prime} \mathrm{E}$ & DGGE, $p m o A, m x a F$ \\
\hline 28 & $76^{\circ} 34.95^{\prime} \mathrm{N}$ & $19^{\circ} 02.41^{\prime} \mathrm{E}$ & DGGE, $p m o A, m x a F$ \\
\hline RS & $70^{\circ} 35.91^{\prime} \mathrm{N}$ & $10^{\circ} 51.59^{\prime} \mathrm{E}$ & {$\left[\mathrm{CH}_{4}\right], \mathrm{MO}_{\mathrm{x}}$-rates time series } \\
\hline
\end{tabular}

ter sampling (Schmitt et al., 1991). Hydrocarbon concentrations were measured with a Chrompack 9003 gas chromatograph (GC) equipped with a flame ionization detector (FID). Duplicate measurements indicate an error of 5-10\% (Lammers and Suess, 1994). After GC analyses, an aliquot of the extracted $\mathrm{CH}_{4}$ gas was transferred into pre-evacuated glass containers for stable carbon isotope analysis performed with an isotope ratio mass spectrometer (IRMS; Finnigan Delta XP plus) in our onshore laboratories. The extracted gas was purged and trapped with the PreCon equipment (Finnigan) to preconcentrate the sample. All isotopic ratios have an analytical error $<1 \%$ and are presented in the $\delta$ notation against the Vienna Pee Dee Belemnite (VPDB) standard.

\subsection{Methane oxidation rates}

$\mathrm{MO}_{\mathrm{x}}$ rates were determined from ex situ incubations of water samples in $100 \mathrm{~mL}$ serum vials. The vials were filled bubblefree from Niskin bottles and crimped with rubber stoppers (halogenated butyl elastomer). One set of samples was then incubated with $50 \mu \mathrm{L}$ of ${ }^{3} \mathrm{H}$-labeled $\mathrm{CH}_{4}(160-210 \mathrm{kBq})$ in $\mathrm{N}_{2}$, and a second set was incubated with $10 \mu \mathrm{L}$ of ${ }^{14} \mathrm{C}$ labeled $\mathrm{CH}_{4}(12-15 \mathrm{kBq}) .{ }^{3} \mathrm{H}-\mathrm{CH}_{4}$ tracer addition raised ambient $\mathrm{CH}_{4}$ concentrations by $1-2 \mathrm{nM}$ and ${ }^{14} \mathrm{C}_{-}-\mathrm{CH}_{4}$ addition by $440-540 \mathrm{nM}$. The samples were subsequently shaken for $\sim 10 \mathrm{~min}$ on an orbital shaker to facilitate tracer dissolution and then incubated in the dark at $2{ }^{\circ} \mathrm{C}$. $\mathrm{CH}_{4}$ oxidation rates $\left(r_{\mathrm{ox}}\right)$ were calculated assuming first-order kinetics (Reeburgh et al., 1991; Valentine et al., 2001):

$r_{\mathrm{ox}}=k^{\prime}\left[\mathrm{CH}_{4}\right]$,

where $k^{\prime}$ is the effective first-order rate constant calculated as the fraction of labeled $\mathrm{CH}_{4}$ oxidized per unit time, and $\left[\mathrm{CH}_{4}\right]$ is the in situ $\mathrm{CH}_{4}$ concentration. In order to determine a suitable incubation time period, we performed parallel time series incubations with samples collected from the fjord (stations 2 and 18) and from an open-water station (reference 
station - RS). During each incubation series, tracer consumption was measured in duplicates after a time period of $0.5,1$, 2, 3, 4 and 5 days. In the $\mathrm{CH}_{4}$-rich waters of the fjord, our results showed a linear tracer consumption of about 5-15\% over the first three days of incubation (Fig. 3). A potential bias due to substrate limitation and/or variations in reaction velocity thus seems negligible, at least over a time period of 3 days, which we chose for our ex situ incubations. Just as the time series incubations, vertical distribution of $\mathrm{MO}_{\mathrm{x}}$ was determined in duplicates.

Incubations with ${ }^{3} \mathrm{H}-\mathrm{CH}_{4}$ and measurements of ${ }^{3} \mathrm{H}-\mathrm{CH}_{4}$ and ${ }^{3} \mathrm{H}-\mathrm{H}_{2} \mathrm{O}$ were carried out according to Valentine et al. (2001) and Mau et al. (2012). Briefly, total activity $\left({ }^{3} \mathrm{H}-\right.$ $\mathrm{CH}_{4}+{ }^{3} \mathrm{H}-\mathrm{H}_{2} \mathrm{O}$ ) was measured in $1 \mathrm{~mL}$ of sample aliquot by wet scintillation counting, and activity of ${ }^{3} \mathrm{H}-\mathrm{H}_{2} \mathrm{O}$ was measured after sparging the sample for $>30$ min with $\mathrm{N}_{2}$ to remove remaining ${ }^{3} \mathrm{H}-\mathrm{CH}_{4}$.

Incubations with ${ }^{14} \mathrm{C}-\mathrm{CH}_{4}$ were terminated by injecting $0.5 \mathrm{~mL}$ of $10 \mathrm{M} \mathrm{NaOH}$ and adding a $5 \mathrm{~mL}$ headspace so that the remaining ${ }^{14} \mathrm{C}-\mathrm{CH}_{4}$ accumulated in the headspace and the produced ${ }^{14} \mathrm{C}-\mathrm{CO}_{2}$ and ${ }^{14} \mathrm{C}$ biomass was trapped in the aqueous $\mathrm{NaOH}$ solution. Separation and activity measurement of ${ }^{14} \mathrm{C}_{-} \mathrm{CH}_{4}$ and ${ }^{14} \mathrm{C}-\mathrm{CO}_{2}$ were carried out analogously to previous measurements of $\mathrm{CH}_{4}$ turnover in sediments (Treude et al., 2003; Niemann et al., 2005). In short, ${ }^{14} \mathrm{C}_{-} \mathrm{CH}_{4}$ in the headspace was combusted to ${ }^{14} \mathrm{C}-\mathrm{CO}_{2}$, while ${ }^{14} \mathrm{C}_{-} \mathrm{CO}_{3}^{2-}$ was converted to ${ }^{14} \mathrm{CO}_{2}$ through acidification with $\mathrm{HCI}$. In either case, ${ }^{14} \mathrm{C}-\mathrm{CO}_{2}$ was trapped in a solution of methoxyethanol and phenylethylamine, and the radioactivity was measured by wet scintillation counting. We also measured remaining radioactivity in the sample after ${ }^{14} \mathrm{C}$ $\mathrm{CH}_{4}$ and ${ }^{14} \mathrm{CO}_{3}^{2-}$ removal (probably ${ }^{14} \mathrm{C}$ incorporated into biomass), which ranged between 4 and $84 \%$ (average $35 \%$ ) of the total product.

\subsection{Diversity of $\mathrm{MO}_{\mathrm{x}}$ community}

The diversity of the natural bacterioplankton assemblages was examined by denaturing gradient gel electrophoresis (DGGE) based on the 16S rRNA gene. Immediately after sampling, bacterial cells were concentrated on Nuclepore filters $(0.2 \mu \mathrm{m}$ pore size $)$ and the filters were stored frozen at $-20^{\circ} \mathrm{C}$ until DNA extraction. Total community DNA was extracted using the UltraClean Soil DNA Kit (MoBio Laboratories, USA). One to five microliters of DNA extract was applied as the template in the 16S rRNA gene specific PCR, with GM5 plus GC-clamp as the forward primer and 907RM as the reverse primer (Muyzer et al., 1993). PCR conditions were as described by Gerdes et al. (2005). PCR products (ca. $500 \mathrm{bp}$ ) were analyzed by DGGE based on the protocol of Muyzer et al. (1993) using a gradient chamber. Clearly visible bands of the DGGE pattern were excised from the gel and reamplified by PCR (Gerdes et al., 2005) and sequenced. The 16S rRNA gene sequences were then assigned to the new higher-order taxonomy proposed in Bergey's taxonomic

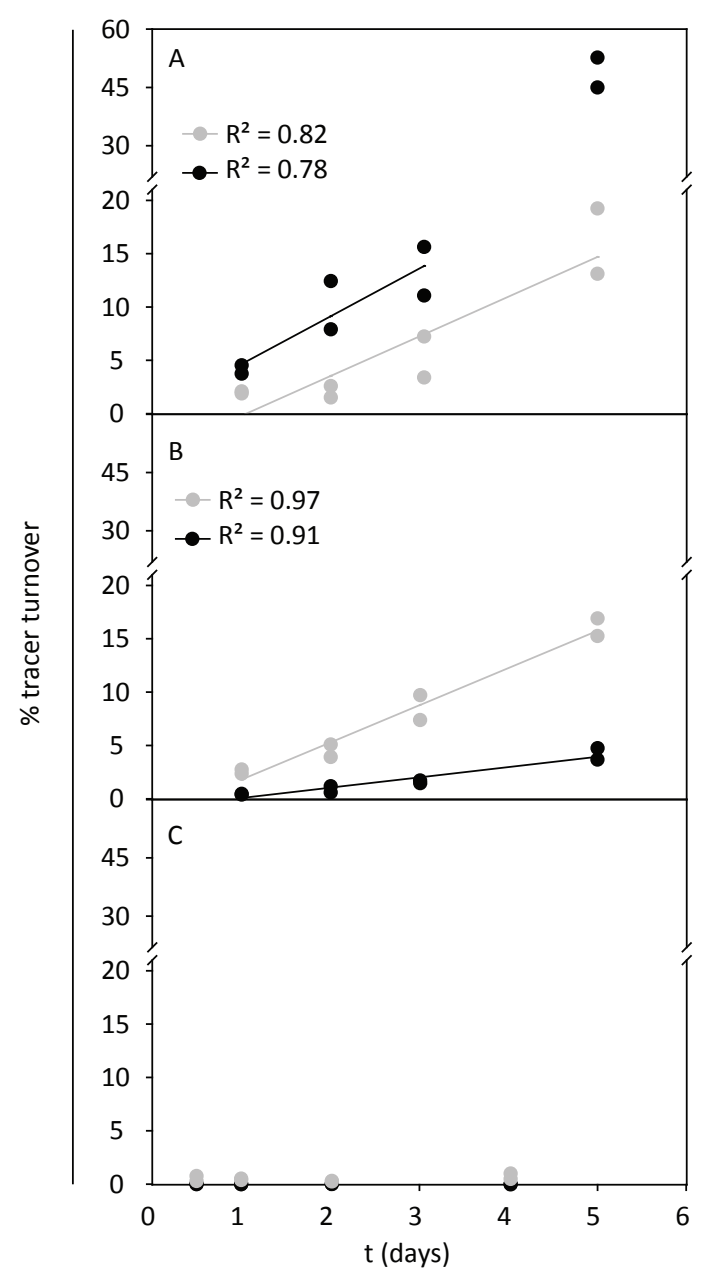

Fig. 3. Time series incubation of water samples collected at (A) station $2\left(77^{\circ} 5.226^{\prime} \mathrm{N}\right.$ and $\left.19^{\circ} 29.694^{\prime} \mathrm{E}\right)$ at $135 \mathrm{~m}$ water depth, at (B) station $18\left(78^{\circ} 15.288^{\prime} \mathrm{N}\right.$ and $\left.19^{\circ} 29.070^{\prime} \mathrm{E}\right)$ at $50 \mathrm{~m}$ water depth, and at $(\mathbf{C})$ a reference station $\left(\mathrm{RS}, 70^{\circ} 35.91^{\prime} \mathrm{N}\right.$ and $\left.10^{\circ} 51.59^{\prime} \mathrm{E}\right)$ at $101 \mathrm{~m}$ water depth. ${ }^{14} \mathrm{C}-\mathrm{CH}_{4}$ and ${ }^{3} \mathrm{H}-\mathrm{CH}_{4}$ results are shown as black and gray circles, respectively.

outline of the "Prokaryotes" by the "Ribosomal Database Project (RDP) Classifier" (Wang et al., 2007). The sequences were further compared with those deposited in GenBank using the BLAST algorithm.

The presence of $\mathrm{CH}_{4}$-oxidizing bacteria in the communities was screened by the two functional primer sets "pmoA" and "mxaF", targeting the genes encoding subunits of the particulate methane monooxygenase (pMMO) and the methanol dehydrogenase (MDH), respectively. Both enzymes are key enzymes for methanotrophs (e.g., McDonald et al., 2008). However, the $m x a F$ gene is also present in almost all other methylotrophic bacteria. The primer sets and amplification conditions employed in the gene-specific PCR reaction are described in Holmes et al. (1995) and McDonald and Murrell (1997), respectively. 


\section{Results}

\subsection{Water column biogeochemistry}

According to Skogseth et al. (2005), we could identify three distinct water masses: melt water, MW $\left(T:>0.0^{\circ} \mathrm{C}, S\right.$ : $<34.2)$; Arctic water, $\operatorname{ArW}\left(T:<0.0^{\circ} \mathrm{C}, S: 34.3-34.8\right)$; and brine-enriched shelf water, BSW $\left(T:<-1.5^{\circ} \mathrm{C}, S:>4.8\right)$ (Fig. 4d).

The MW extended from the surface to $\sim 60 \mathrm{~m}$ water depth; this is the depth range where the thermocline is located and temperature decreased by $\sim 4{ }^{\circ} \mathrm{C}$ (Fig. $4 \mathrm{a}$ ). In the MW, $\mathrm{CH}_{4}$ concentrations increased from $\sim 20 \mathrm{nM}$ at the surface to $72.3 \mathrm{nM}$ at $60 \mathrm{~m}$ water depth (Fig. 5a). All concentrations were high and oversaturated with respect to the atmospheric equilibrium concentration of 3.3-3.9 nM (at the relevant $T / S$ conditions, Wiesenburg and Guinasso, 1979). Similar to concentrations, microbial oxidation rates determined with ${ }^{3} \mathrm{H}-$ and ${ }^{14} \mathrm{C}$ tracer increased with depth to $2.3 \mathrm{nM} d a y^{-1}$ and $0.77 \mathrm{nM} \mathrm{day}^{-1}$, respectively, at $60 \mathrm{~m}$ (Fig. $5 \mathrm{~b}$ and c). In the MW, rates measured with ${ }^{14} \mathrm{C}$ tracer $\left(440-540 \mathrm{nM}{ }^{14} \mathrm{C}_{-} \mathrm{CH}_{4}\right.$ added) were consistently lower than those determined with ${ }^{3} \mathrm{H}$ tracer $\left(1-2 \mathrm{nM}^{3} \mathrm{H}-\mathrm{CH}_{4}\right.$ added). $\delta^{13} \mathrm{C}_{-} \mathrm{CH}_{4}$ values in this water mass ranged between -43.5 and $-53.6 \%$ (Fig. $5 \mathrm{~d}$ ).

In the ArW, (60 to $\sim 100 \mathrm{~m}$ water depth) oxygen concentrations decreased with depth from 350 to $320 \mu \mathrm{M}$ (Fig. 4c) and $\mathrm{CH}_{4}$ concentrations from 42 to $6.5 \mathrm{nM}$ (Fig. 5a). Both $\mathrm{MO}_{\mathrm{x}}$ rates determined with ${ }^{3} \mathrm{H}$ and ${ }^{14} \mathrm{C}$ tracer showed a maximum at $\sim 80 \mathrm{~m}$ in this water mass (Fig. $5 \mathrm{~b}$ and c). The stable carbon isotopic signature of $\mathrm{CH}_{4}$ showed a strong shift from -46 to about $-32 \%$ at $\sim 80 \mathrm{~m}$ (Fig. $5 \mathrm{~d}$ ).

The BSW (>100 m water depth) was characterized by oxygen concentrations below $320 \mu \mathrm{M}$ (Fig. 4c). $\mathrm{CH}_{4}$ concentrations decreased slightly with depth, but were stable below $120 \mathrm{~m}$ (8-9 nM, Fig. 5a). $\mathrm{MO}_{\mathrm{x}}$ rates determined with ${ }^{3} \mathrm{H}$-labeled $\mathrm{CH}_{4}$ showed a similar trend to the $\mathrm{CH}_{4}$ concentrations. However, while ${ }^{3} \mathrm{H}-\mathrm{MO}_{\mathrm{x}}$ rates (approximately in situ rates) were low, rates determined with ${ }^{14} \mathrm{C}$-labeled $\mathrm{CH}_{4}$ (rates determined at elevated $\mathrm{CH}_{4}$ concentrations) were comparably high, with a maximum of $1.9 \mathrm{nM} \mathrm{day}^{-1}$ at $\sim 100 \mathrm{~m}$ water depth (Fig. 5b and c). The carbon isotopic signature of the $\mathrm{CH}_{4}$ decreased steadily from its maximum of $-30 \%$ at $100 \mathrm{~m}$ to $-39 \%$ in the lowermost sample ( $136 \mathrm{~m}$, Fig. $5 \mathrm{~d})$.

\subsection{Microbial communities}

\subsubsection{DGGE of 16S rDNA}

Similar to the biogeochemical results, the MW and BSW at the studied stations (stations. 2, 5, 12, 18, 19) showed distinct DGGE banding patterns (Fig. 6, Table 2) indicating that surface MW and deep waters were populated by different microbial communities.

The MW samples showed strong DGGE bands that we could assign to eukaryotic-chloroplast DNA (\#3, \#4) and to
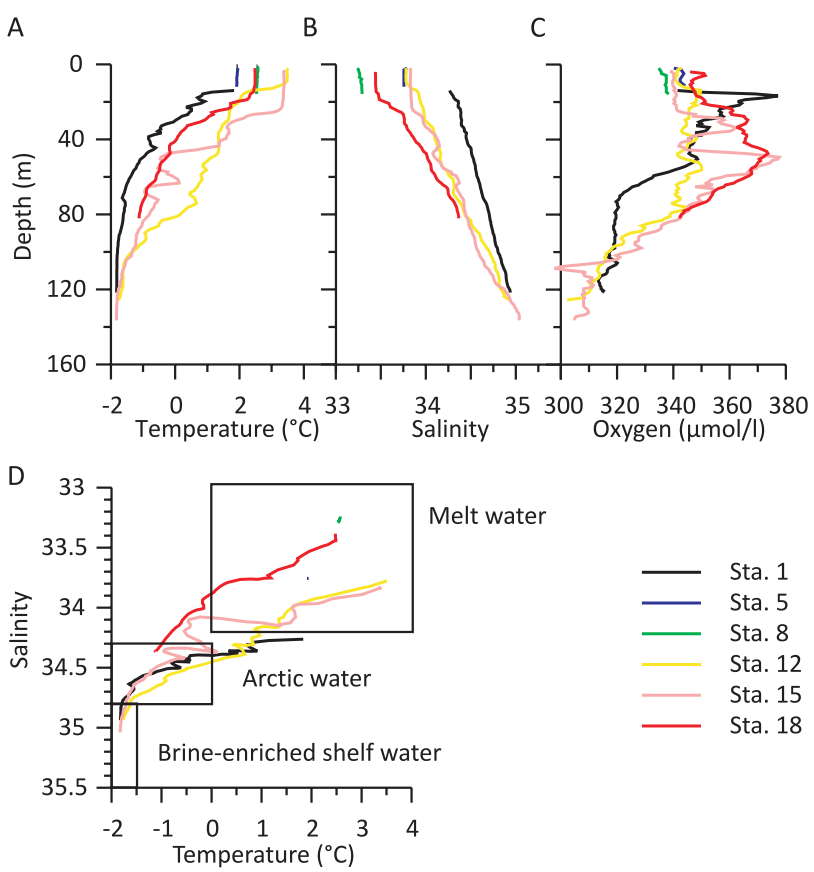

Fig. 4. Depth profiles of temperature (A), salinity (B), and oxygen concentrations $(\mathbf{C})$, as well as a temperature-salinity graph with temperature-salinity ranges of the dominant water masses in Storfjorden (D). Stations 5 and 8 are less than $20 \mathrm{~m}$ deep and appear as dots in the temperature-salinity graph.

Alphaproteobacteria of the genera Phaeobacter and Sulfitobacter (\#7, \#8). The affiliation to the genus Phaeobacter was, however, relatively weak ( 0.51 confidence value, Table 2$)$, indicating a possibly yet-undescribed bacteria type. Additional bands (\#5, \#9, and \#11) could be assigned to the genera Fluviicola within the phylum Bacteroidetes, Haliea within the phylum Proteobacteria, and llumatobacter within the phylum Actinobacteria. Although we could measure $\mathrm{CH}_{4}$ oxidation in the surface waters, the DGGE based on the 16S rRNA gene did not reveal known methanotrophs.

In contrast to the diverse MW community, all deep-water samples (station 12,127 m; station 2, $138 \mathrm{~m}$; station 18 , $136 \mathrm{~m}$ ) showed a quite low diversity with only two strong (\# 6 and \#7) and one weaker DGGE band (\#10) (Fig. 6). Band \#7 was also common in the upper water masses, while band \#6 was only found in the BSW samples. This band could be affiliated with Methylosphaera, which is a known type I $\mathrm{MO}_{\mathrm{x}}$ bacterium (Bowman et al., 1997). However, the confidence value of 0.38 was relatively low (Table 2 ). The deepwater-specific band \#10 could be assigned to the sulphate reducer Desulfobacca, also with a relatively low confidence level (0.19, Table 2).

\subsubsection{Molecular marker genes of methanotrophs}

The $p m o A$ gene that encodes the alpha subunit of the particulate methane monooxygenase is a molecular marker gene 


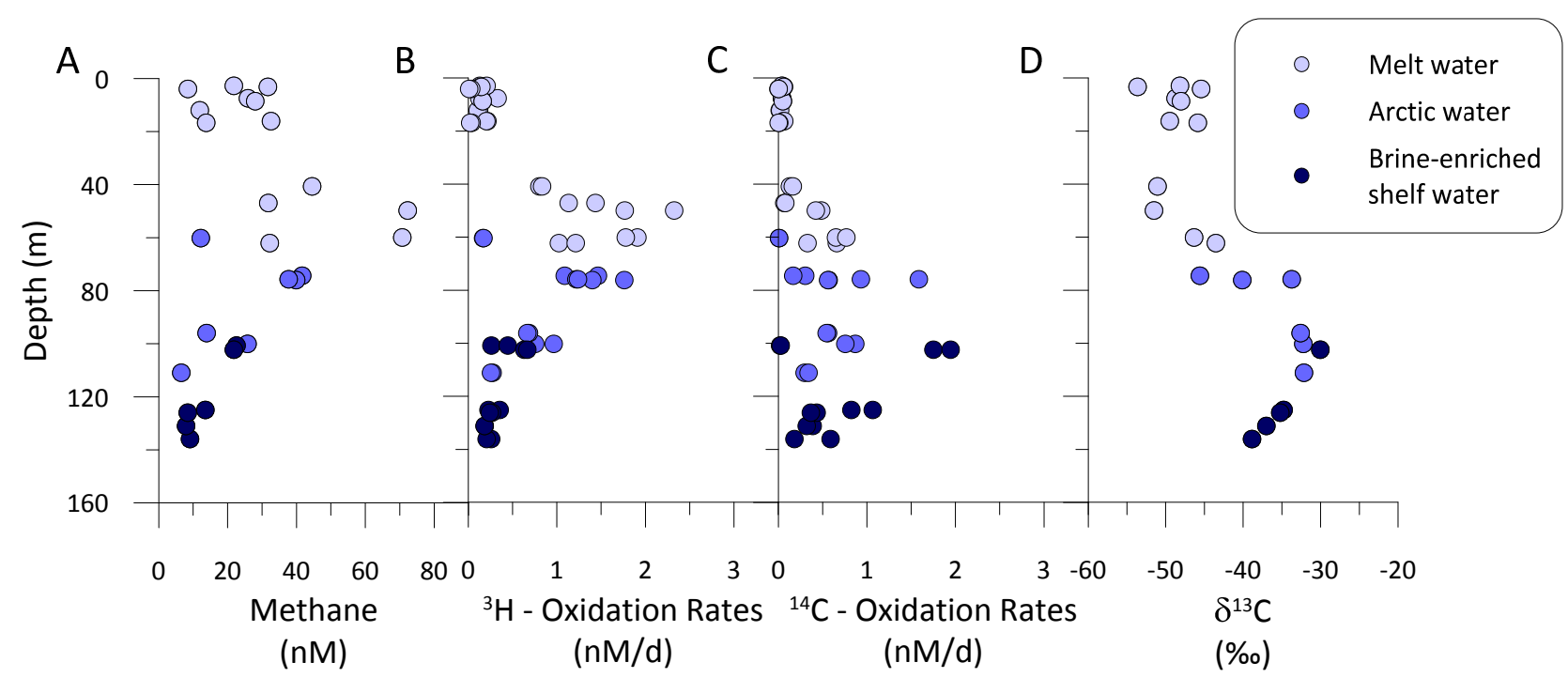

Fig. 5. Depth profiles of $\mathrm{CH}_{4}$ concentrations (A), oxidation rates derived by ${ }^{3} \mathrm{H}_{-} \mathrm{CH}_{4}-(\mathbf{B})$ and ${ }^{14} \mathrm{C}_{-} \mathrm{CH}_{4}$ tracer $(\mathbf{C})$, and $\mathrm{CH}_{4}$ stable carbon isotope composition $\left(\delta^{13} \mathrm{C}\right.$ values, D). Samples are color-coded according to the water masses (Fig. 4).

Table 2. Classification of partial $16 \mathrm{~S}$ rRNA sequences to bacterial taxa performed with the RDP Classifier (Wang et al., 2007). The confidence value (0-1) for assignment at the level of class and genus is given in parentheses.

\begin{tabular}{lll}
\hline No. & Class & Genus \\
\hline 1 & Alphaproteobacteria $(1)$ & Cand. Pelagibacter $(1)$ \\
2 & Flavobacteria $(1)$ & Polaribacter $(1)$ \\
3 & Cyanobacteria $(1)$ & Chlorophyta $(0.98)$ \\
4 & Cyanobacteria $(1)$ & Chlorophyta $(1)$ \\
5 & Flavobacteria $(1)$ & Fluviicola $(0.81)$ \\
6 & Gammaproteobacteria $(1)$ & Methylosphaera $(0.38)$ \\
7 & Alphaproteobacteria $(1)$ & Phaeobacter $(0.51)$ \\
8 & Alphaproteobacteria $(1)$ & Sulfitobacter $(0.97)$ \\
9 & Gammaproteobacteria $(1)$ & Haliea $(1)$ \\
10 & Deltaproteobacteria $(0.27)$ & Desulfobacca $(0.19)$ \\
11 & Actinobacteria $(1)$ & Ilumatobacter $(1)$ \\
\hline
\end{tabular}

of methanotrophs (McDonald et al., 2008). In contrast to the $16 \mathrm{~S}$ rRNA-based survey, the pmoA-based PCR yielded amplicons within all surface- and deep-water samples (Fig. 7) attesting to the ubiquitous presence of $\mathrm{MO}_{\mathrm{x}}$ communities in waters of Storfjorden. However, besides the expected product of $530 \mathrm{bp}$, all deep-water samples showed a further, longer amplicon. Nevertheless, none of the $>530 \mathrm{bp}$ amplicons could be affiliated with known $p m o A$ genes, which suggests either novel pmoA types or unspecific PCR products. A similar distinction of the water masses was also apparent from the distribution of the $m x a F$ gene (Fig. 7) that encodes the enzyme methanol dehydrogenase, which catalyzes the second step in $\mathrm{CH}_{4}$ oxidation. The mxaF gene was also found in all samples, but deep-water samples showed several additional, weak, and shorter mxaF bands.

\section{Discussion}

\subsection{Water column stratification and methane sources}

Storfjorden water column mixing regimes were the subject of several previous publications (e.g., Haarpaintner et al., 2001; Skogseth et al., 2005; Fer, 2006). The fjord is a deep semi-enclosed basin in the Svalbard Archipelago characterized by brine formation as a result of ice formation in latent heat polynyas during wintertime (Haarpaintner et al., 2001). Descending brines induce strong vertical mixing (Jardon et al., 2011) and turbulence at the sediment-water interface. However, accumulation of brine in bottom waters also leads to a stabilization of the water column, which is further enhanced through a $\sim 60 \mathrm{~m}$ thick surface layer of relatively saltdepleted MW in summertime (Fig. 4). The residence time of the deep BSW is 90-246 days, relatively long compared to the 51-141 days of the surface water (Geyer et al., 2009), so that ongoing oxygen consumption leads to the comparably low oxygen levels that were detected previously (Anderson et al., 1988) and in this study.

$\mathrm{CH}_{4}$ concentrations in Storfjorden are generally high, at 6-72 nM. These elevated concentrations originate from microbial methanogenesis in the sediments and enhanced transport from sediments into the water column as a result of the descending brines inducing turbulence at the sedimentwater interface (Damm et al., 2007). However, $\mathrm{CH}_{4}$ concentrations indicate a second $\mathrm{CH}_{4}$ source at 40-60 m water depth (Fig. 5a). Here $\mathrm{O}_{2}$ concentrations were high as well (Fig. 4c), 


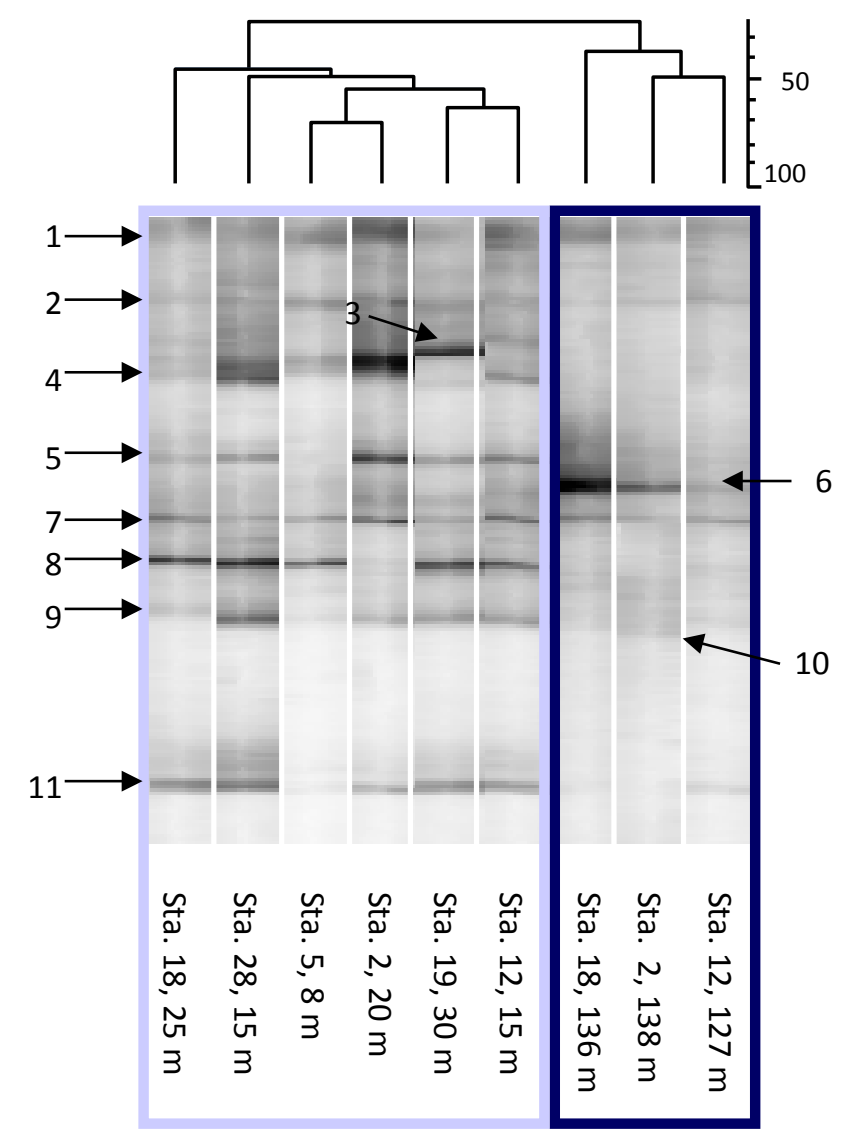

Fig. 6. DGGE profile of $16 \mathrm{~S}$ rRNA gene fragments of MW and BSW samples from different stations in Storfjorden. Numbers on the left-hand side of the lanes indicate excised and successfully sequenced DGGE bands, whose phylogenetic assignment is listed in Table 2. MW and BSW samples are framed by a light-blue and dark-blue rectangle, respectively. Dendrogram derived from UPGMA cluster analysis with the similarity coefficient of Jaccard.

possibly indicating a maximum of phytoplankton. The second $\mathrm{CH}_{4}$ source could thus be related to water column in situ production by yet unidentified microorganisms utilizing the phytoplankton metabolite DMSP as a carbon source (Damm et al., 2008) or microbially produced MPn as a potential phosphorus source (Karl et al., 2008; Metcalf et al., 2012). However, further investigations are required to determine the role of these compounds as potential $\mathrm{CH}_{4}$ precursors at Storfjorden.

While a significant fraction of the $\mathrm{CH}_{4}$ is consumed (see Sect. 4.2), Storfjorden is apparently a $\mathrm{CH}_{4}$ source to the atmosphere (Damm et al., 2007), as indicated by $\mathrm{CH}_{4}$ concentrations of up to $30 \mathrm{nM}$ in the well-mixed surface layer. These concentrations are highly supersaturated with respect to the atmospheric equilibrium (3.3-3.9 nM, Wiesenburg and Guinasso, 1979).

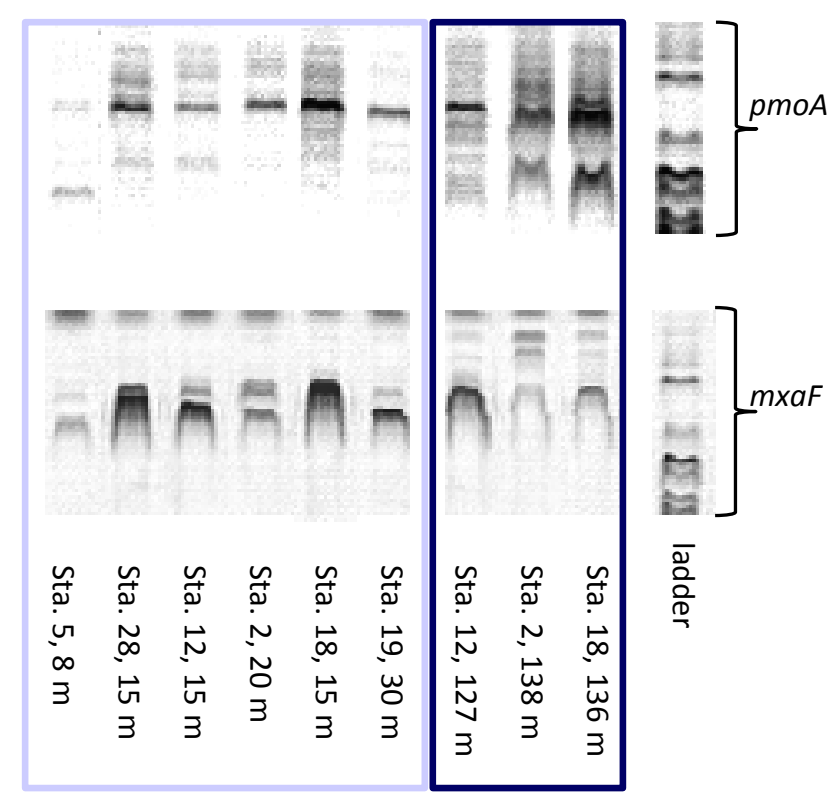

Fig. 7. Agarose-electrophoresis gels of PCR products of the pmoA and $m x a F$ genes obtained from surface MW and deep BSW water samples of different stations in Storfjorden. MW and BSW samples are framed by a light-blue and dark-blue rectangle, respectively.

\subsection{Vertical distribution of methane oxidation}

Maximum $\mathrm{MO}_{\mathrm{x}}$ rates in the water column of Storfjorden were $\sim 2 \mathrm{nMday}^{-1}$, and are thus very similar to $\mathrm{MO}_{\mathrm{x}}$ rates measured in the Santa Barbara Basin (Pack et al., 2011; Mau et al., 2012) and the Black Sea (Reeburgh et al., 1991), which are both well-known areas of large methane input (Fig. 1). However, our rates are 3 orders of magnitude lower compared to the measurements conducted after the Deep Water Horizon accident in the Gulf of Mexico, during which catastrophic amounts of hydrocarbons were released into the water column, triggering a rapid response in $\mathrm{MO}_{\mathrm{x}}$ activity (Valentine et al., 2010; Kessler et al., 2011). Other $\mathrm{MO}_{\mathrm{x}}$ rate measurements were conducted in Bristol Bay and the southeast Bering Sea (Griffith et al., 1982), the Cariaco Basin (Ward et al., 1987), Saanich Inlet (Ward, 1989 and Ward and Kilpatrick, 1990), in Southern California Bight (Ward, 1992; Pack et al, 2011; Heintz et al., 2012; Ward and Kilpatrick, 1993), in the Eel River basin (Valentine et al., 2001), the Gulf of Mexico (Kelley, 2003), and at hydrothermal vents at Juan de Fuca Ridge (de Angelis et al., 1991, 1993). It appears that most of these $\mathrm{MO}_{\mathrm{x}}$ rates fall into the range between 0.001 and $10 \mathrm{nM} \mathrm{day}^{-1}$ and that $\mathrm{MO}_{\mathrm{x}}$ activity is elevated in ocean environments with high $\mathrm{CH}_{4}$ concentrations. However, $\mathrm{MO}_{\mathrm{x}}$ activity in the surface- (Ward, 1992; Kelley, 2003, this study) and open ocean (Sauter et al., 2006) seems to be rather low.

In addition to these larger-scale trends, our results from Storfjorden indicate distinct and vertically separated regimes of $\mathrm{CH}_{4}$ oxidation. This distinction is apparent when 
comparing $\mathrm{MO}_{\mathrm{x}}$ rates in deep BSW ( $>100 \mathrm{~m}$ ) with surface MW $(<60 \mathrm{~m})$. The ArW (60-100 m) appears to be an intermediate between the two regimes (Fig. $5 \mathrm{~b}$ and c). We incubated parallel samples with ${ }^{3} \mathrm{H}$ - and ${ }^{14} \mathrm{C}$-labeled $\mathrm{CH}_{4}$. While absolute rate measurements with ${ }^{3} \mathrm{H}-\mathrm{CH}_{4}$ were moderate in ArW and BSW, rates with ${ }^{14} \mathrm{C}_{-} \mathrm{CH}_{4}$ were elevated in these water masses. We suggest that this is related to the different amounts of $\mathrm{CH}_{4}$ that were added as a result of ${ }^{3} \mathrm{H}-\mathrm{CH}_{4}$ compared to ${ }^{14} \mathrm{C}_{-} \mathrm{CH}_{4}$ application. While in incubations with ${ }^{3} \mathrm{H}-\mathrm{CH}_{4}$, the final $\mathrm{CH}_{4}$ concentrations were only raised by $<2 \mathrm{nM},{ }^{14} \mathrm{C}_{-} \mathrm{CH}_{4}$ amendments lead to a $\mathrm{CH}_{4}$ increase of $\sim 450 \mathrm{nM}$. It is therefore reasonable to assume that the activity of the deep-water $\mathrm{MO}_{\mathrm{x}}$ community was stimulated as a result of elevated $\mathrm{CH}_{4}$ concentrations (Pack et al., 2011). This is most likely related to enzyme kinetics (Ward and Kilpatrick, 1990; Bender and Conrad, 1993; Smith et al., 1997), which can be described with the Michaelis-Menten model (Button, 1985; Johnson and Goody, 2011, translation of the 1913 Michaelis-Menten paper). The Michaelis-Menten relation shows that enzyme activity, expressed by the reaction rate, increases hyperbolically with substrate concentration but levels off once the enzymatic machinery involved in the metabolic pathway is saturated with substrate. Similar relations were found between cell- or community-specific rates and substrate concentrations (Button, 2010, and references therein). For a stable community, a maximum rate thus exists, which may only increase as a result of elevated enzyme concentrations (e.g., population growth) and/or optimization of cytoarchitectural components relevant for substrate metabolism (e.g., transporter system). We could show that substrate turnover rates were linear over the incubation time period of three days (Fig. 3). At least for our incubation experiments, it thus seems unlikely that the $\mathrm{CH}_{4}$ amendments induced an increase in enzyme concentration or optimization of other parameters relevant for substrate metabolism.

The derivative of the Michaelis-Menton function for low substrate concentrations $\left(\mathrm{CH}_{4}\right.$ concentrations lower than half saturation constant, $k_{\mathrm{m}}$ ) yields the first-order rate constant $\left(k^{\prime}\right)$, which, multiplied with the substrate concentration, defines the actual rate $\left(r_{\mathrm{ox}}\right.$; see Eq. 1). Consequently, under substrate-limiting conditions, $k^{\prime}$ values are high but decrease if substrate concentrations approach enzyme saturation level. This relationship is depicted in Fig. 8. In MW (the fjord's surface layers), $k^{\prime}$ values were high during ${ }^{3} \mathrm{H}-\mathrm{CH}_{4}$ incubations, i.e., without substantial $\mathrm{CH}_{4}$ amendments, but the addition of $\mathrm{CH}_{4}$ in the ${ }^{14} \mathrm{C}-\mathrm{CH}_{4}$ incubations led to a substantial decrease (5-10 fold) in $k^{\prime}$, which suggests enzyme saturation. On the other hand, the deep-water community in ArW and particularly in BSW appeared to operate at $\mathrm{CH}_{4}$ concentrations below saturation because the addition of $\mathrm{CH}_{4}$ through ${ }^{14} \mathrm{C}_{-} \mathrm{CH}_{4}$ tracer application led to an increase in $k^{\prime}$ compared to parallel incubations with ${ }^{3} \mathrm{H}-\mathrm{CH}_{4}$.

It should be noted that rate measurements with two different substrate concentrations (we added $2 \mathrm{nM}$ and $450 \mathrm{nM}$ ) are not useful for a kinetic study yielding $k_{\mathrm{m}}$ and/or the max-

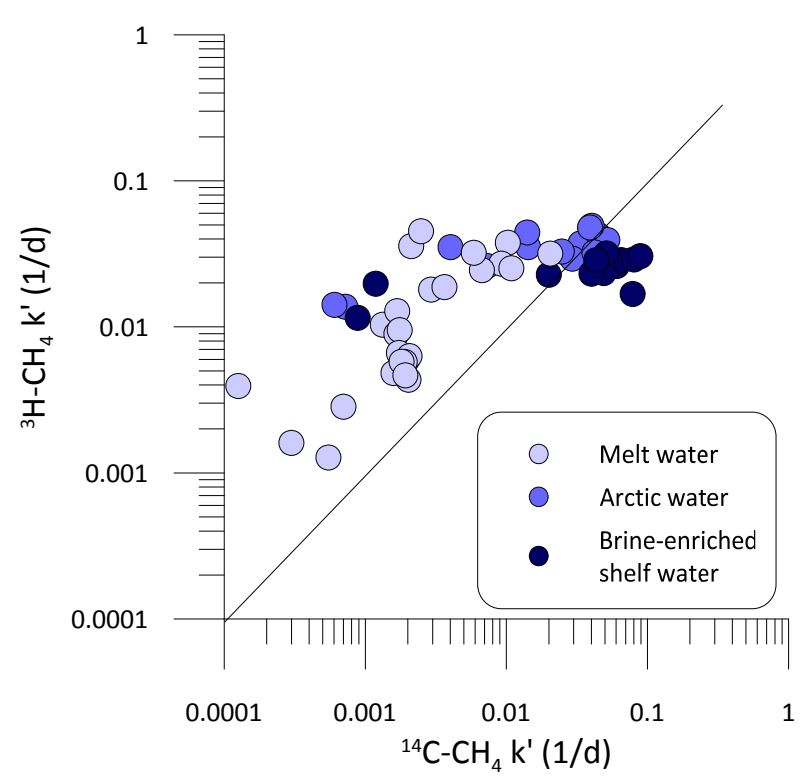

Fig. 8. Comparison of rate constants $\left(k^{\prime}\right)$ determined with ${ }^{3} \mathrm{H}-\mathrm{CH}_{4}-$ and ${ }^{14} \mathrm{C}-\mathrm{CH}_{4}$ tracers. Straight line shows the $1: 1$ fit; that is, if $k^{\prime}$ derived from both tracers were equal. Samples from surface melt water fall above this line $\left(k^{\prime}\right.$ determined by ${ }^{3} \mathrm{H}-\mathrm{CH}_{4}$ is higher than $k^{\prime}$ derived by $\left.{ }^{14} \mathrm{C}_{-}-\mathrm{CH}_{4}\right)$ and samples from the deep brine-enriched shelf water mainly fall below this line $\left(k^{\prime}\right.$ determined by ${ }^{14} \mathrm{C}_{-}-\mathrm{CH}_{4}$ is higher than $k^{\prime}$ derived by ${ }^{3} \mathrm{H}-\mathrm{CH}_{4}$ ).

imum reaction velocity $\left(v_{\max }\right)$. Nevertheless, adaptation to different substrate concentrations, as indicated by our results, can (at least in parts) be explained by the Michaelis-Menten concept. The $\mathrm{MO}_{\mathrm{x}}$ community inhabiting the deeper water masses, which are periodically exposed to high $\mathrm{CH}_{4}$ concentrations, seems to be adapted to high $\mathrm{CH}_{4}$ substrate levels. In contrast, the community inhabiting surface waters with generally low $\mathrm{CH}_{4}$ concentrations seems not to be adapted to metabolize additional $\mathrm{CH}_{4}$, which could be related to a low enzymatic $k_{\mathrm{m}}$. Low $k_{\mathrm{m}}$ values, which were found to range between $10 \mathrm{nM}$ and $10 \mu \mathrm{M}$ (e.g., Bender and Conrad, 1993, Baani and Liesack, 2008), could indeed explain this phenomenon. However, the available $k_{\mathrm{m}}$ values from the literature were determined from organisms found in terrestrial or freshwater environments or from cultured bacteria, which most likely do not represent the rather unknown marine communities. Furthermore, the enzymatic $k_{\mathrm{m}}$ may not be the same as the apparent cell/community-based $k_{\mathrm{m}}$ (see discussion by Button, 2010).

The question remains as to why the $\mathrm{MO}_{\mathrm{x}}$ communities in deep and surface waters were apparently adapted to high and low $\mathrm{CH}_{4}$ concentrations, respectively. Relatively low $\mathrm{CH}_{4}$ concentrations in deeper water layers seem to be a regular feature of Storfjorden, at least during summertime (Damm et al., 2008). However, during wintertime, $\mathrm{CH}_{4}$ export from the sediments is enhanced, leading to elevated $\mathrm{CH}_{4}$ concentration of up to $\sim 60 \mathrm{nM}$ with a $\delta^{13} \mathrm{C}$-signature of -40 to 
$-50 \%$ in deeper water layers of Storfjorden (Damm et al., 2007). It thus appears reasonable to assume that the deepwater community is adapted to comparably high wintertime $\mathrm{CH}_{4}$ concentrations. In summertime, ongoing $\mathrm{CH}_{4}$ oxidation leads to decreasing $\mathrm{CH}_{4}$ concentrations and an increase in ${ }^{13} \mathrm{C}$ in the residual $\mathrm{CH}_{4}$ (Fig. 5). In contrast, surface $\mathrm{CH}_{4}$ seems only to increase strongly during summer (to $\sim 50 \mathrm{nM}$ ), potentially as a result of $\mathrm{CH}_{4}$ production in the oxic water column. However, we cannot explain why surface-water methanotrophs appear not to have adapted to the high summertime $\mathrm{CH}_{4}$ concentrations or possibly lack the ability to adapt.

\subsection{Microbial community}

Similar to the $\mathrm{MO}_{\mathrm{x}}$ regimes, the diversity of the bacterial assemblage was different when comparing surface MW to the deep BSW. Our DGGE analyses indicate a higher microbial diversity in surface- compared to the deep water (Fig. 6, Table 2). Nevertheless, we only found one band in the surface water (\#9) and one band in the deep water (\#6) that might be related to $\mathrm{CH}_{4}$ oxidizers. Band \#9 could be affiliated to the genus Haliea of which novel isolates were found to oxidize ethylene and to possess genes similar to those encoding pMMO (Suzuki et al., 2012). Band \#6 could be assigned to a known aerobic methanotroph of the genus Methylosphaera (yet with a relatively low confidence value of 0.38). Species of the order Methylosphaera were previously found in Antarctic marine salinity, meromictic lakes (Bowman et al., 1997). The different patterns of $\mathrm{MO}_{\mathrm{x}}$-related bands in surface- and deep water thus indicate the presence of different $\mathrm{MO}_{\mathrm{x}}$ communities in these water masses.

Similar to the 16S gene rRNA-based survey, the pmoA and $m x a F$ gene analyses indicated differences between surfaceand deep-water masses (Fig. 7). All samples analyzed generated amplicons with both primer sets; the deep-water samples, however, showed an additional, longer pmoA band and several weak, shorter $m x a F$ bands suggesting the presence of different, and possibly novel, $p m o A$ - and $m x a F$-related gene sequences or unspecific PCR products. Similar suggestions (novel sequences or unspecific PCR products) were given in other studies using the pmoA primers, which we used, resulting in a limited coverage of the methanotrophic diversity and yielding PCR products that could also not be assigned to known pmoA types (Bourne et al., 2001; Henckel et al., 2000, Tavormina et al., 2008). Nevertheless, in addition to the $16 \mathrm{~S}$ banding pattern and $\mathrm{MO}_{\mathrm{x}}$ rates at elevated $\mathrm{CH}_{4}$ concentrations, this further indicates that surface- and deep waters comprise different $\mathrm{MO}_{\mathrm{x}}$ communities.

The question remains as to what are the driving mechanisms for the development of the $\mathrm{MO}_{\mathrm{x}}$ communities in the different water masses. Here, we suggest that resuspension of sediments as a result of turbulent mixing during wintertime could have inoculated the deeper water masses with sediment microbes including benthic $\mathrm{MO}_{\mathrm{x}}$ communities. These are of- ten distinct from planktonic communities (Bowman et al., 1997; He et al., 2012; Tavormina et al., 2008), and probably adapted to higher $\mathrm{CH}_{4}$ concentrations. This scenario would also explain the presence of the sulfate reducer Desulfobacca in the oxic deep waters. Sulfate-reducing bacteria are usually adapted to an anoxic environment (e.g., sediments), and may tolerate only low $\mathrm{O}_{2}$ levels, yet resting cells of sulfate reducers were also found in fully oxygenated waters (Hastings and Emerson, 1988; Teske et al., 1996). In contrast to the deep waters, the comparably short residence time of surface waters and the rather rapid exchange with the Barents Sea argues for a planktonic source of $\mathrm{MO}_{\mathrm{x}}$ communities in this water mass.

\section{Conclusions}

Incubation experiments with different substrate levels (here we used different tracers) are useful to identify distinct methanotrophic responses in different water masses. With respect to the natural $\mathrm{CH}_{4}$ concentrations of our study site ( $<80$ nM, Fig. 5), we used ${ }^{3} \mathrm{H}-\mathrm{CH}_{4}$ amendments, which altered absolute $\mathrm{CH}_{4}$ concentrations by $1-2 \mathrm{nM}$. The ${ }^{14} \mathrm{C}_{-} \mathrm{CH}_{4}$ amendments, in contrast, increased $\mathrm{CH}_{4}$ concentrations by $440-540 \mathrm{nM}$. The ${ }^{3} \mathrm{H}-\mathrm{CH}_{4}$ ex situ tracer incubations thus yield rates that may be similar to in situ rates. ${ }^{14} \mathrm{C}_{-} \mathrm{CH}_{4}$ ex situ rates were within the same order of magnitude as those determined with ${ }^{3} \mathrm{H}-\mathrm{CH}_{4}$. Yet, because of the high $\mathrm{CH}_{4}$ concentration increase during our incubations with ${ }^{14} \mathrm{C}_{-} \mathrm{CH}_{4}$, these ex situ rates rather provide an indication for the rate potential of the $\mathrm{MO}_{\mathrm{x}}$ community. Rate measurements typically provide a temporal snapshot, which is difficult to upscale, particularly in environments with spatiotemporally varying $\mathrm{CH}_{4}$ fluxes. Knowledge on the $\mathrm{MO}_{\mathrm{x}}$ rate at elevated $\mathrm{CH}_{4}$ concentrations, on the other hand, provides a means to estimate the response in $\mathrm{MO}_{\mathrm{x}}$ activity in relation to changing $\mathrm{CH}_{4}$ fluxes.

Acknowledgements. We are indebted to the captain, crew, and scientific research party of the research vessel Heincke (cruise HE-333), especially to the organizer and chief scientist Michael Schlüter. We would like to thank Antje Boetius, Gabriele Schüßler, and Gunter Wegener from the Max Planck Institute for Marine Microbiology (Bremen, Germany) for providing scientific equipment and laboratory support. We are grateful to Jutta Jürgens from Alfred Wegener Institute for Marine and Polar Research (Bremerhaven, Germany), who implemented the microbial analyses. Susan Mau was funded through a Marie Curie Outgoing International Fellowship (MOIF-CT-2006-021604) of the European Community. Jan Blees was funded through a COST Short Term Scientific Mission (COST-STSM-ES0902-6596) and the Swiss National Science Foundation (SNF grant 121861).

The service charges for this open access publication have been covered by the Max Planck Society.

Edited by: C. Woulds 


\section{References}

Anderson, L. G., Jones, E. P., Lindegren, R., Rudels, B., and Sehlstedt, P.-1.: Nutrient regeneration in cold, high salinity bottom water of the Arctic shelves, Cont. Shelf Res., 8, 1345-1355, 1988.

Baani, M. and Liesack, W.: Two isozymes of particulate methane monooxygenase with different methane kinetics are found in Methylocystis sp. strain SC2, P. Natl. Acad. Sci., 105, 1020310208, 2008.

Barnes, R. O. and Goldberg, E. D.: Methane production and consumption in anoxic marine sediments, Geology, 4, 297-300, 1976.

Bender, M. and Conrad, R.: Kinetics of methane oxidation in oxic soils, Chemosphere, 26, 687-769, 1993.

Bourne, D. G., McDonald, I. R., and Murell, J. C: Comparison of pmoA PCR primer sets as tools for investigating methanotroph diversity in three Danish soils, Appl. Environ. Microbiol., 67, 3802-3809, 2001.

Bowman, J. P., McCammon, S. A., and Skerratt, J. H.: Methylosphaera hansonii gen. nov, sp. nov, a psychrophilic, group I methanotroph from Antarctic marine-salinity, meromictic lakes, Microbiology, 143, 1451-1459, 1997.

Button, D. K: Kinetics of nutrient-limited transport and microbial growth, Microbiol. Rev, 49, 270-297, 1985.

Button, D. K.: Mud volcanoes, in: Handbook of Hydrocarbon and Lipid Microbiology, edited by: Timmis, K. N., Springer, NY, 1638-1647, 2010.

Damm, E., Schauer, U., Rudels, B., and Haas, C.: Excess of bottomreleased methane in an Arctic shelf sea polynya in winter, Cont. Shelf Res., 27, 1692-1701, 2007.

Damm, E., Kiene, R. R, Schwarz, J., Falck, E., and Dieckmann, G.: Methane cycling in Arctic shelf water and its relationship with phytoplankton biomass and DMSP, Mar. Chem., 109, 4559, 2008.

Damm, E., Helmke, E., Thoms, S., Schauer, U., Nöthig, E., Bakker, K., and Kiene, R. P.: Methane production in aerobic oligotrophic surface water in the central Arctic Ocean, Biogeosciences, 7, 1099-1108, doi:10.5194/bg-7-1099-2010, 2010.

de Angelis, M. A., Baross, J. A., and Lilley, M. D.: Enhanced microbial methane oxidation in water from a deep-sea hydrothermal vent field at simulated in situ hydrostatic pressures, Limnol. Oceanogr., 36, 565-570, 1991.

de Angelis, M. A., Lilley, M. D, Olson, E. J., and Baross, J. A.: Methane oxidation in deep-sea hydrothermal plumes of the Endeavour Segment of the Juan de Fuca Ridge, Deep-Sea Res. I, 40, 1169-1186, 1993.

Fer, I.: Scaling turbulent dissipation in an Arctic fjord, Deep-Sea Res. II, 53, 77-95, 2006.

Formolo, M.: The microbial production of methane and other volatile hydrocarbons, in: Handbook of Hydrocarbon and Lipid Microbiology, edited by: Timmis, K. N., Springer, NY, 113-126, 2010.

Gerdes, B., Brinkmeyer, R., Dieckmann, G., and Helmke, E.: Influence of crude oil on changes of bacterial communities in Arctic sea-ice, FEMS Microbiol. Ecol., 53, 129-139, 2005.

Geyer, F., Fer, I., and Eldevik, T: Dense overflow from an Arctic fjord: Mean seasonal cycle, variability and wind influence, Cont. Shelf Res., 29, 2110-2121, 2009.

Griffiths, R. P., Caldwell, B. A., Cline, J. D, Broich, W. A., and Morita, R. Y: Field observations of methane concentrations and oxidation rates in the southeastern Bering Sea, Appl. Environ. Microbiol., 44, 435-446, 1982.

Haarpaintner, J., Gascard, J. C, and Haugan, P. M.: Ice production and brine formation in Storfjorden, Svalbard, J. Geophys. Res., 106, 14001-14013, 2001.

Hanson, R. S. and Hanson, T E.: Methanotrophic bacteria, Microbiol. Rev., 60, 439-471, 1996.

Hastings, D. and Emerson, S.: Sulfate reduction in the presence of low oxygen levels in the water column of the Cariaco Trench, Limnol. Oceanogr., 33, 391-396, 1988.

He, R., Wooller, M. J., Pohlman, J. W., Quensen, J., Tiedje, J. M., and Leigh, M. B.: Shifts in identity and activity of methanotrophs in Arctic lake sediments in response to temperature changes, Appl. Environ. Microb., 78, 4715-4728, 2012.

Henckel, T., Jäckel, U., Schnell, S., and Conrad, R.: Molecular analyses of novel methanotrophic communities in forest soil that oxidize atmospheric methane, Appl. Environ. Microbiol., 66, 18011808, 2000.

Heintz, M., Mau, S., and Valentine, D. L: Physical control on methanotrophic potential in waters of the Santa Monica Basin, Southern California, Limnol. Oceanogr., 57, 420-432, 2012.

Hinrichs, K. U. and Boetius, A.: The anaerobic oxidation of methane: new insights in microbial ecology and biogeochemistry, in: Ocean Margin Systems, edited by: Wefer, G., Billett, D., Hebbeln, D., Jorgensen, B. B., Schluter, M., and van Weering, T., Springer Verlag, Heidelberg, 457-477, 2002.

Holmes, A. J., Costello, A., Lidstrom, M. E., and Murell, J. C: Evidence that particulate methane monooxygenase and ammonia monooxygenase may be evolutionary related, FEMS Microbiol. Lett., 132, 203-208, 1995.

IPCC: Climate Change 2007 - The Physical Science Basis - Contribution of Working Group I to the Fourth Assessment Report of the Intergovernmental Panel on Climate Change, edited by: Solomon, S., Qin, D., Manning, M., Marquis, M., Averyt, K., Tignor, M. M. B., and LeRoy Miller, H. J., Cambridge University Press, Cambridge, 2007.

Jardon, F. P., Bouruet-Aubertot, P., Cuypers, Y., Vivier, F., and Lourenco, A.: Internal waves and vertical mixing in the Storfjorden Polynya, Svalbard, J. Geophys. Res.-Oceans, 116, C12040, doi:10.1029/2010JC006918, 2011.

Johnson, K. A. and Goody, R. S.: The original Michaelis constant: translation of the 1913 Michaelis-Menten paper, Biochemistry, 50, 8264-8269, 2011.

Karl, D. M., Beversdorf, L., Bjoerkman, K. M., Church, M. J., Martinez, A., and DeLong, E. F: Aerobic production of methane in the sea, Nat. Geosci., 1, 473-478, 2008.

Kelley, C: Methane oxidation potential in the water column of two diverse coastal marine sites, Biogeochemistry, 65, 105-120, 2003.

Kessler, J. D., Valentine, D. L., Redmond, M. C., Du, M., Chan, E. W., Mendes, S. D., Quiroz, E. W., Villanueva, C. J., Shusta, S. S., Werra, L. M., Yvon-Lewis, S. A., and Weber, T. C.: A persistent oxygen anomaly reveals the fate of spilled methane in the deep Gulf of Mexico, Science, 331, 312-315, 2011.

Knittel, K. and Boetius, A.: Anaerobic oxidation of methane: progress with an unknown process, Ann. Rev. Microbiol., 63, 311-334, 2009.

Lammers, S. and Suess, E.: An improved head-space analysis method for methane in seawater, Mar. Chem., 47, 115-125, 1994. 
Loeng, H.: Features of the physical oceanographic conditions of the Barent Sea, in: Proceedings of the Pro Mare Symposium on Polar Marine Ecology, edited by: Sakshaug, E., Hopkins, C. C. E., and Øritsland, N. A., Polar Research, Trondheim, 5-18, 1991.

Martens, C. S. and Berner, R. A.: Interstitial water chemistry of anoxic Long Island Sound sediments. I. Dissolved gases, Limnol. Oceanogr., 22, 10-25, 1977.

Mau, S., Rehder, G., Arroyo, I. G., Gossler, J., and Suess, E.: Indications of a link between seismotectonics and $\mathrm{CH}_{4}$ release from seeps off Costa Rica, Geochem. Geophy. Geosy., 8, Q04003, doi:10.1029/2006GC001326, 2007a.

Mau, S., Valentine, D. L, Clark, J. R, Reed, J., Camilli, R., and Washburn, L: Dissolved methane distributions and air-sea flux in the plume of a massive seep field, Coal Oil Point, California, Geophys. Res. Lett., 34, L22603, doi:10.1029/2007GL031344, $2007 b$.

Mau, S., Heintz, M. B., and Valentine, D. L: Quantification of $\mathrm{CH}_{4}$ loss and transport in dissolved plumes of the Santa Barbara Channel, California, Cont. Shelf Res., 32, 110-120, 2012.

McDonald, I. R. and Murrell, J. C: The particulate methane monooxygenase gene $p m o A$ and its use as a functional gene probe for methanotrophs, FEMS Microbiol. Lett., 156, 205-210, 1997.

McDonald, I. R., Bodrossy, L., Chen, Y., and Murrell, J. C.: Molecular ecology techniques for the study of aerobic methanotrophs, Appl. Environ. Microb., 74, 1305-1315, 2008.

Metcalf, W. W., Griffin, B. M., Cicchillo, R. M., Gao, J., Chandra Janga, S., Cooke, H. A., Cir-cello, B. T, Evans, B. S., MartensHabbena, W., Stahl, D. A., and van der Donk, W. A.: Synthesis of methylphosphonic acid by marine microbes: a source for methane in the aerobic ocean, Science, 337, 1104-1107, 2012.

Murrell, J. C.: The aerobic methane oxidizing bacteria (Methanotrophs), in: Handbook of Hydrocarbon and Lipid Microbiology, edited by: Timmis, K. N., Springer, 1953-1966, 2010.

Muyzer, G., de Waal, E., and Uitterlinden, A.: Profiling of complex microbial populations by denaturing gradient gel electrophoresis analysis of polymerase chain reaction-amplified genes coding for 16S rRNA, Appl. Environ. Microbiol., 59, 695-700, 1993.

Niemann, H., Elvert, M., Hovland, M., Orcutt, B., Judd, A., Suck, I., Gutt, J., Joye, S., Damm, E., Finster, K., and Boetius, A.: Methane emission and consumption at a North Sea gas seep (Tommeliten area), Biogeosciences, 2, 335-351, doi:10.5194/bg2-335-2005, 2005.

Niemann, H., Duarte, J., Hensen, C, Omoregie, E., Magalhaes, V H., Elvert, M., Pinheiro, L. M., Kopf, A., and Boetius, A.: Microbial methane turnover at mud volcanoes of the Gulf of Cadiz, Geochim. Cosmochim. Ac., 70, 5336-5355, 2006.

Pack, M. A., Heintz, M. B., Reeburgh, W. S., Trumbore, S. E., Valentine, D. L., Xu, X., and Druffel, E. R. M.: A method for measuring methane oxidation rates using low-levels of $14 \mathrm{C}$ labeled methane and accelerator mass spectrometry, Limnol. Oceanogr., 9, 245-260, 2011.

Reeburgh, W. S.: Methane consumption in Cariaco Trench waters and sediments, Earth Planet. Sci. Lett., 28, 337-344, 1976.

Reeburgh, W. S.: Oceanic methane biogeochemistry, Chem. Rev., 107, 486-513, 2007

Reeburgh, W. S., Ward, B. B., Whalen, S. C, Sandbeck, K. A., Kilpatrick, K. A., and Kerkhof, L. J.: Black Sea methane geochemistry, Deep-Sea Res., 38, S1189-S1210, 1991.
Sauter, E., Muyakshin, S. I., Charlou, J. L., Schlüter, M., Boetius, A., Jerosch, K., Damm, E., Foucher, J. P., Klages, M.: Methane discharge from a deep-sea submarine mud volcano into the upper water column by gas hydrate-coated methane bubbles, Earth Planet. Sci. Lett., 243, 354-365, 2006.

Schmitt, M., Faber, E., Botz, R., and Stoffers, P.: Extraction of methane from seawater using ultrasonic vacuum degassing, Anal. Chem., 63, 529-532, 1991.

Skogseth, R., Haugan, P. M., and Jakobsson, M.: Watermass transformations in Storfjorden, Cont. Shelf Res., 25, 667-695, 2005.

Smith, K. S., Costello, A. M., and Lidstrom, M. E.: Methane and trichloroethylene oxidation by an estuarine methanotroph, Methylobacter sp. strain BB5.1, Appl. Environ. Microbiol., 63, 4617-4462, 1997.

Suzuki, T., Nakamura, T., and Fuse, H.: Isolation of two novel marine ethylene-assimilating bacteria, Haliea species ETY-M and ETY-NAG, containing particulate methane monooxygenase-like genes Microbes Environ., 27, 54-60, 2012.

Tavormina, P. L, Ussier III, W., and Orphan, V. J.: Planktonic and sediment-associated aerobic methanotrophs in two seep systems along the North American Margin, Appl. Environ. Microbiol., 74, 3985-3995, 2008.

Teske, A., Wawer, C, Muyzer, G., and Ramsing, N. B.: Distribution of sulfate-reducing bacteria in a stratified fjord (Mariager fjord, Denmark) as evaluated by most-probable-number counts and denaturing gradient gel electrophoresis of PCR-amplified ribosomal DNA fragments, Appl. Environ. Microbiol., 62, 1405-1415, 1996.

Treude, T., Boetius, A., Knittel, K., Wallmann, K., and Jorgensen, B. B.: Anaerobic oxidation of methane above gas hydrates at Hydrate Ridge, NE Pacific Ocean, Mar. Ecol.-Prog. Ser., 264, 1-14, 2003.

Valentine, D. L, Blanton, D. C, Reeburgh, W. S., and Kastner, M.: Water column methane oxidation adjacent to an area of active hydrate dissociation, Eel River Basin, Geochim. Cosmochim. Ac., 65, 2633-2640, 2001.

Valentine, D. L., Kessler, J. D., Redmond, M. C., Mendes, S. D., Heintz, M. B., Farwell, C., Hu, L., Kinnaman, F. S., Yvon-Lewis, S., Du, M., Chan, E. W., Tigreros, F. G., and Villanueva, C. J.: Propane respiration jump-starts microbial response to a deep oil spill, Science, 330, 208-211, 2010.

Wang, Q., Garrity, G. M., Tiedje, J. M., and Cole, J. R.: Naive Bayesian classifier for rapid assignment of rRNA sequences into the new bacterial taxonomy, Appl. Environ. Microbiol., 73, 5261-5267, 2007.

Ward, B. B.: The subsurface methane maximum in the Southern California Bight, Cont. Shelf Res., 12, 735-752, 1992.

Ward, B. B. and Kilpatrick, K. A.: Relationship between substrate concentration and oxidation of ammonium and methane in a stratified water column, Cont. Shelf Res., 10, 1193-1208, 1990.

Ward, B. B. and Kilpatrick, K. A.: Methane oxidation associated with mid-depth methane maxima in the Southern California Bight, Cont. Shelf Res., 13, 1111-1122, 1993.

Ward, B. B., Kilpatrick, K. A., Novelli, P. C., and Scranton, M. I.: Methane oxidation and methane fluxes in the ocean surface layer and deep anoxic waters, Nature, 327, 226-229, 1987.

Ward, B. B., Kilpatrick, K. A., Wopat, A. E., Minnich, E. C, and Lidstrom, M. E.: Methane oxidation in Saanich inlet during summer stratification, Cont. Shelf Res., 9, 65-75, 1989. 
Whiticar, M. J.: Carbon and hydrogen isotope systematics of bacterial formation and oxidation of methane, Chem. Geol., 161, 291314, 1999.
Wiesenburg, D. A. and Guinasso, J. N. L: Equilibrium solubilities of methane, carbon monoxide, and hydrogen in water and sea water, J. Chem. Eng. Data, 24, 356-360, 1979. 